\title{
Resale of Option Stock Acquired under Form S-8: A Case for Expanding the Use of Rule 144
}

Securities offered to an issuing company's employees through stock option plans frequently constitute part of the issuing company's total compensation package. ${ }^{1}$ Such plans are attractive to employers because of the financial interest in the success of the enterprise which the plans tend to inspire in employees and because the plans avoid a drain on the employer's cash. More importantly, there are considerable tax benefits which accrue to both employer and employees.2

It is the broad purpose of the Securities Act of $1933^{3}$ to provide investors with material financial and other information concerning securities offered for sale and to prohibit misrepresentation and fraud in the sale of securities generally. Most option stock that is issued to a significant number of employees by a company with a broad public market for its securities has been registered under the 1933 Act on Form S-8, the registration statement ${ }^{4}$ which the Securities and

1. See 1 G. Washington \& V. Rothschild, Comipensating the Corporate Executive 153.58 (3d ed. 1962).

2. See INT. REv. CoDE of 1954, $\$ \$ 422-24$. Indeed, much of the continuing vitality of stock options as a form of compensation can be traced to the imagination of tax lawyers. For a review of the impact of the federal tax laws on stock options, see Childs, Compensating the Executive After the Tax Reform Act with Stock Options, Restricted Stock, Deferred Pay-and Even Cash, 48 TAxes 801 (1970); Engel, Nontraditional Forms of Compensation After the Tax Reform Act of 1969, U. So. CaL. 1972 TAX INST. 587, 594-95; Rice, "Restricted Stock" as Executive Incentives: Interplay Between IRC Section 83 and SEC Rule 1H, 28 Bus. LAw. 127 (1972); Symposium, Current Problems and Developments in Executive Compensation, N.Y.U. 29TH INST. ON FED. TAX. 1195-1341 (1971).

3. 15 U.S.C. $\$ \S 77 a-77 a a ~(1970)$ (popularly known as the $1933 \mathrm{Act}$ ).

4. For the reader who is uninitiated to the intricacies of securities regulation law, an introduction to certain terminology is appropriate here. When securities are offered for sale, they have to be "registered," unless the securities or the transaction qualifies for one of the 1933 Act's exemptions. Securities become registered when a "registration statement" containing information concerning the issuer and the securities being offered thereunder is filed with the SEC and permitted by the SEC after its review to become effective. In the sale of option stock, the employees to whom the options are granted are known as "optionees." When an optionce disposes of the stock which he acquired by exercising his option, he is said to engage in a "resale." Prior to the time when securities are acquired by members of the "investing public" (i.e., persons who do not have unusual access to, and a capacity for analysis of, information regarding the issuer and who acquire the securities for investment purposes), a "distribution" of the securities is said to be involved. See p. 91 infra. One who participates in any stage of a distribution is said to be an "underwriter." See note 32 infra. Currently, the SEC staff regards the optionee as an underwriter upon resale if he is in a position to control the management of the issuer (i.e, if he is a "control person") (officers, directors, and those who own a controlling block of voting securities of the issuer might be in such a position; see SEC Rule $405(\mathrm{f})$, 17 C.F.R. $\$ 230.405(\mathrm{f})(1974)$ ) or if he acquires a substantial proportion of the original offering (i.e., if he is a "substantial optionholder"). 
Exchange Commission (SEC) has provided explicitly for this purpose. ${ }^{5}$ While Form S-8 may provide adequate investor protection to the optionees, it does not provide a member of the investing public who subsequently acquires the securities from an optionee with as much disclosure or protection as he would receive if he acquired the securities directly from the issuer. ${ }^{6}$ In an attempt to compensate for this, the SEC subjects the optionee to restrictions ${ }^{7}$ upon resale if he is an underwriter as to such securities. The optionee may be deemed an underwriter by virtue of several concepts, but the SEC's definition of "underwriter" is by no means limited to the large investment companies the layman would associate with the term. In the context of an S-8 offering of option stock, the securities holder is considered an underwriter if he acquires a substantial proportion of the offering or if he is a control person of the issuer.

This Note examines the protection afforded by Form S-8 and the restrictions which are currently imposed on the resale of S-8 securities. It argues that in some instances these restrictions provide less investor protection than might otherwise be obtained, that in other instances they unfairly impose liability on the optionee, and that in still other instances they unnecessarily impair the liquidity of the securities. These are substantial defects. The SEC is currently reviewing S-8 resale procedures, ${ }^{8}$ and should therefore use the occasion to alter its regulatory scheme. A model for change is available: Resales of S-8 securities should be regulated as resales of nonrestricted securities are currently regulated under SEC Rule $144 .^{9}$

\section{The S-8 Registration Statement}

The S-8 registration statement (Form S-8) was adopted ${ }^{10}$ in response to the acknowledged need of employees for some protection when they acquire securities directly from an issuer as part of a compen-

5. SEC Form S-8, 17 C.F.R. \$ 239.16b (1974).

6. See note 14 infra.

7. While this Note will focus solely upon the restrictions which arise from the $1933 \mathrm{Act}$, this is not to belittle the restrictions which might arise from the Securities Exchange Act of 1934, 15 U.S.C. $\$ \$$ 78a-78jj (1970) (popularly known as the 1934 Act), through SEC Rule 10b-6, 17 C.F.R. $\$ 240.10 \mathrm{~b}-6$ (1974) (prohibition against sales by persons interested in a distribution) and Section 16(b) of that Act (prohibition against insider short-swing trading) (see in particular SEC Rule 16b-3, 17 C.F.R. $\$ 240.16 \mathrm{~b}-3$ (1974), and SEC Rule 16b-6, 17 C.F.R. \$ 240.16b-6 (1974).

8. SEC Securities Act Release No. 5530 (Oct. 10, 1974).

9. SEC Rule 144, 17 C.F.R. $\$ 230.144$ (1974)

10. SEC Securities Act Release No. 3480 (June 16, 1953) (adopted); SEC Securities Act Release No. 3469-X (Apr. 12, 1953) (proposed). 
sation plan. ${ }^{11}$ Registration on Form $S-1,{ }^{12}$ the registration statement an issuer must file for a nonexempt offering where no other form is authorized or prescribed, seemed too costly ${ }^{13}$ for this purpose both for the issuer and for the SEC, which must devote staff time to review any statement before permitting it to become effective. The SEG accordingly developed Form S-8, which requires substantially less information from the issuer than would be required by Form S-1.14 The SEC justifies this reduced disclosure on the grounds that the issuer's employees have access to more information than do members of the investing public. ${ }^{15}$

11. In SEC v. Ralston Purina Co., 346 U.S. 119 (1953), it was held that an offering of treasury stock to certain of the issuer's employees as part of a compensation plan was not exempt from the registration requirements of the 1933 Act, absent a showing of special circumstances. The Court stated that:

The exemption [relating to nonpublic offerings found in Section $4(2)$ of the $1933 \mathrm{Act}]$, as we construe it, does not deprive corporate employees, as a class, of the safeguards of the Act. We agree that some offerings may come within [that exemption], e.g., one made to executive personnel who because of their position have access to the same kind of information that the Act would make available in the form of a registration statement. Absent such a showing of special circumstances, employees are just as much members of the investing 'public' as any of their neighbors in the community.

346 U.S. at $125-26$.

12. SEC Form S-1, 17 C.F.R. $\$ 239.11$ (1974).

13. See SEC, Cost of Flotation of Registered Equity Securities 1963-1965, at 10-11 (1970). As early as 1941, the SEC expressed concern over the burden imposed by a full registration statement on Form $S-1$ for an offering of securities pursuant to a compensation plan. SEC Securities Act Release No. 2485 (Feb. 27, 1941).

14. As compared with Form S-1, Form S-8 lacks information concerning the plan of distribution of the securities, the organization of the issuer, the issuer's business, property held by the issuer, legal proceedings in which the issuer may be involved, the issuer's directors, officers, and their remuneration, and material transactions between the issuer and its management. SEC Form S-8, 1 CCH FED. SEC. L. REP. rq $7198-99$ (1974); SEC Form S-1, I CCH FED. SEC. L. REP. T 7123-24 (1974). Not only is significantly more information made available to the investing public in an S-1 offering, but that expanded information is also subject to the scrutiny of an independent underwriter, underwriter's counsel, an independent auditor, issuer's counsel, and the staff of the SEC. For a brief description of the process, see Note, Resale of Restricted Securities under SEC Rule 144, 81 YALE L.J. 1574, 1579 (1972).

15. When Form S.8 was first adopted, the SEC justified its use on the basis of the reduced price at which securities registered thereon were normally obtained, stating that "most employee stock purchase plans provide an opportunity for the accumulation by employees of securities of the employer upon favorable terms," so that "the investment decision required to be made by the employee is of a substantially different character than is involved where securities offered for the purposes of raising capital are sold upon the best obtainable terms." SEC Securities Act Release No. 3480, at 1 (June 16, 1953). This argument is suspect because the fact that employees may be obtaining securities at a discount is independent of the employee's need for protection; at best, this merely indicates that the employee's losses, if any, will be mitigated. Moreover, the factual premise of the argument is incorrect. The expanded use of Form S.8 to include option stock means that many options registered thereon will be granted at market price. Accordingly, the SEC has turned to the employee's allegedly lesser need for protection as a justification for permitting the use of the Form. The SEC states that "because of the knowledge which the employees may be presumed to have about the Company, the form permits the omission of certain information ..." SEC Securities Act Release No. 4844, at 1 (Aug. 5, 1966). This justification is not necessarily in conflict with SEC v. Ralston Purina Co., 346 U.S. 119 (1953), which held only that an offering to an issuer's employees was not exempt from the registration requirements of the 1933 Act, absent a showing of special circumstances. Id. at 
Initially, Form S-8 could be used only for registering securities sold pursuant to employee stock purchase plans. When interest in stock options increased, Form S-8 was amended ${ }^{16}$ to make it available for registering securities underlying "restricted stock options," 17 which were particularly popular because of the tax benefits afforded them. When these tax benefits were replaced by those afforded "qualified"18 and "employee stock purchase plan"19 options, Form S-8 was amended to make it available for registering stock underlying those options, and currently proposed amendments may further expand its use. ${ }^{20}$

Form S-8 may be used only by an issuer that is a reporting company ${ }^{21}$ under the Securities Exchange Act of $1934,{ }^{22}$ so that prior to its use there is an existing background of up-to-date, publicly available information regarding the issuer. It is important to note, however, that the various reports filed by a reporting company contain rather less detailed information than the S-1 registration statement and are not the occasion for the intensive investigation of the company as

126. Just how much protection a particular registration is to provide is within the discretion of the SEC. Securities Act of $1933 \S 10(a)(4), 15$ U.S.C. $\$ 77 \mathrm{j}(\mathrm{a})(4)$ (1970). However, dicta in the opinion indicate that the court regarded an employee as needing just as much protection as any member of the investing public. 346 U.S. at 126.

16. SEC Securities Act Release No. 4533 (Aug. 30, 1962).

17. A "restricted stock option" had to be granted in connection with the optionee's employment, could not run for more than ten years, had to specify a price not less than 85 percent of the value of the stock when the option was granted, and had to meet certain other requirements. Employees who owned directly or cosstructively more than ten percent of the issuer's voting stock could not participate. INT. REv. Code of 1954, $\$ 424$ (b). Restricted stock options issued after December 31, 1963, do not qualify for the tax benefits previously afforded. Id. This type of stock option continues to be popular, however, and Form $S \cdot 8$ has been amended to make it available for registering securities underlying stock options which would be defined as "restricted" but for the date of their issuance. SEC Securities Act Release No. 4733 (Nov. 20, 1964).

18. A "qualified stock option" must be granted pursuant to a plan approved by the stockholders, may not run for more than five years, must specify a price equal to or greater than the value of the stock when the option is granted, and must meet certain other requirements. Employees who own directly or constructively more than a specified percentage of the issuer's stock (five or ten percent, depending on the amount of the issuer's equity capital) may not participate. INT. REv. CODE oF 1954, $\$ 422(\mathrm{~b})$.

19. "Employee stock purchase plans" must be open to a broad spectrum of employees, and no more than $\$ 25,000$ of stock may accrue for purchase per employee per year. Employees owning directly or constructively five percent or more of the issuer's stock are excluded from participation. Id. $\$ 423(\mathrm{~b})$.

20. SEC Securities Act Release No. 4718 (Aug. 27, 1964); SEC Release, supra note 8.

21. A reporting company is subject to the reporting requirements of either Section 13 or $15(d)$ of the Securities Exchange Act of 1934,15 U.S.C. $\$ \S 78 \mathrm{~m}, 78 \mathrm{o}$ (d) (1970). If the company does not have securities listed on a national securities exchange, it must file periodic reports only with the SEC. If the company does have securities listed on a national securities exchange, it must file the same reports with the exchange as well as with the SEC. The reports include "current" reports (reporting material developments affecting the company) (SEC Form 8-K, 17 C.F.R. $\$ 249.308$ (1974)), quarterly reports (SEC Form 10-Q, 17 C.F.R. \$ 249.308a (1974)), and annual reports (SEC Form 10-K, 17 C.F.R. \$ 249.310 (1974); other forms for annual reports also are available for certain issuers).

22. Securities Exchange Act of 1934, 15 U.S.C. $\$ \S 78 \mathrm{a}-78 \mathrm{jj}$ (1970). 
occurs in an S-I registration. ${ }^{23}$ The $S-8$ prospectus is designed to provide optionees with detailed information regarding the compensation plan under which the options are being granted and with certain information regarding the issuer and the securities being offered. ${ }^{24}$ Furthermore, the issuer who registers securities on Form S-8 undertakes $^{25}$ to furnish participating employees with copies of all material distributed from time to time to its stockholders, to transmit that material to the SEC, and to meet the reporting requirements of Section $15(\mathrm{~d})$ of the 1934 Act. $^{26}$

\section{Restrictions on Resale}

Section 5(a) of the 1933 Act requires that a registration statement be in effect ${ }^{2 \tau}$ as to a security at the time of sale, but there are numerous exemptions. ${ }^{28}$ In particular, Section 4(I) exempts "transactions by any person other than an issuer, underwriter, or dealer." A number of the optionees who receive S- 8 securities are free under this provision to resell without registration. ${ }^{29} \mathrm{~A}$ control person or an employee who acquires a substantial proportion of the offering, however, runs a risk of being unable to resell easily. He would be neither an issuer nor a dealer, ${ }^{30}$ but he may be deemed an underwriter and therefore subject to the registration requirements unless some other exemption can be found. If he is subject to the registration requirements, he must ensure that there is an effective registration statement available covering the securities upon his resale. Registration requires, however, detailed information about a company's operations and finances, available as a practical matter only if the issuer cooperates

23. See notes 14,21 supra.

24. SEC Form S-8, I CCH FED. SEC. L. REP. R9 7198-99 (1974). The information regarding the issuer includes a summary statement of the issuer's earnings for the previous five years, a description of recent developments affecting the issuer, a listing of the principal holders of the issuer's equity securities, and copies of the issuer's annual report for the two previous years. The information regarding the securities being optioned includes the range of the market price of those securities over the previous five years and a description of the rights associated with those securities.

25. See SEC Form S-8, Undertakings A, B, I CCH FED. SEC. L. REP. T 7200 (1974).

26. The issuer may subsequently terminate its reporting obligation by certifying that the class of securities registered are held of record by less than 300 persons. Se. curities Exchange Act of $1934 \$ \S 12(\mathrm{~g})(4), 15(\mathrm{~d}), 15$ U.S.C. $\$ \S 781(\mathrm{~g})(4)$, $780(\mathrm{~d})$ (1970).

27. Once declared effective by the SEC, a registration statement will remain current for only nine months after its effective date. Thereafter, it will be considered effective only when the financial statements contained therein are of a date no more than 16 months prior to its desired use. Securities Act of $1933 \S 10(a)(3)$, 15 U.S.C. $\$ 77 j(a)(3)(1970)$.

28. Securities Act of $1933 \$ \$ 3,4,15$ U.S.C. $\$ \$ 77 \mathrm{c}, 77 \mathrm{~d}(1970)$.

29. Digital Information Devices, Inc., [1971-72 Transfer Binder] CCH FED. SEc. L. REP. \ 78,747.

30. See Securities Act of 1933 \$2(12), 15 U.S.C. $\$ 77 \mathrm{~b}(12)$ (1970). 
closely. Depending on his leverage with the issuer, then, the optionholder may simply be unable to meet this requirement. Even if a registration statement is available, he becomes subject to civil liability for false or misleading information contained in the statement. ${ }^{31} \mathrm{Li}$ ability attaches even though he may not be in a position to undertake an investigation into the company's affairs like that customarily provided by commercial underwriters.

\section{A. The Underwriter}

Identifying an underwriter, as that term is defined in the 1933 Act, is a highly subjective determination. An underwriter in general is anyone who acquires securities with a view to their distribution. ${ }^{32}$ A distribution has been held to consist of "the entire process by which in the course of a public offering a block of securities is dispersed and ultimately comes to rest in the hands of the investing public."33 That securities were acquired in a registered offering is not conclusive evidence that they were not acquired with a view to distribution..$^{34}$ In the particular context of an S-8 offering, the SEC staff has stated that an optionee is presumed to be an underwriter if he acquires a substantial proportion of the offering or if he is a control person. ${ }^{35}$

Until early in 1972, those who were presumed to be underwriters under the statute or any regulation could rebut that status by meeting a subjective test establishing their intent not to engage in a distribution. ${ }^{36}$ In general, such a person could meet this test by holding

3I. Id. $\$ 11(\mathrm{a})(5), 15$ U.S.C. $\$ 77 \mathrm{k}(\mathrm{a})(5)(1970)$.

32. Section 2(11) of the Securities Act of 1933, 15 U.S.C. $\$ 77 b(11)$ (1970), provides:

The term "underwriter" means any person who has purchased from an issuer with a view to, or offers or sells for an issuer in connection with, the distribution of any security, or participates or has a direct or indirect participation in any such undertaking, or participates or has a participation in the direct or indirect underwriting of any such undertaking... As used in this paragraph the term

"issuer" shall include, in addition to an issuer, any person directly or indirectly controlling or controlled by the issuer, or any person under direct or indirect common control with the issuer.

See SEC Securities Act Release No. 5223, at 4-5 (Jan. 11, 1972) (SEC's current interpretation of this definition).

33. Oklahoma-Texas Trust, 2 S.E.C. 764, 769 (1937), aff'd, 100 F.2d 888 (10th Cir. 1939)

34. This problem is not unique to S-8 offerings. Even in an S-I new public offering, a person who buys with a view to reselling one or two weeks later might be viewed as an underwriter, in that he took the securities with a view to distribution. His sale may involve a theoretical violation if he is unable to prove that there is no "distribution" as to his reoffer.

35. Tracor, Inc., [1972-73 Transfer Binder] CCH FED. SEc. L. REP. I 79,276; SpectraPhysics, Inc., [1972-73 Transfer Binder] CCH FED. SEc. L. REP. \$ 79,190; Digital Information Devices, Inc., [1971-72 Transfer Binder] CCH FED. SEC. L. REr. f 78,747; Data Packaging Corp., [1971-72 Transfer Binder] CCH FED. SEc. L. REP. T 78,549.

36. Prior to the adoption of Rule 144 in 1972, the SEC, in interpreting the 1933 Act's definition of an underwriter (see note 32 supra), had "traditionally focused on 
the securities for a sufficient period of time, usually two years, ${ }^{37}$ or, if the securities were not held long enough, by establishing that he had encountered an unforeseeable change of circumstances. ${ }^{38}$

Early in 1972, the SEC adopted Rule 144 in an attempt to provide a more objective means by which certain securities holders might overcome their underwriter status and also to provide better investor protection than had been available through the subjective intent test. $^{39}$ In adopting Rule 144, the SEC concomitantly made the subjective intent test considerably less attractive than it had been. While a holding period may be relevant in determining one's intent, it is no longer determinative, nor is the "change in circumstances" test any longer relevant. In addition, the SEC indicated that a much stronger burden of proof would be placed on the person seeking to establish an intent not to engage in a distribution than had formerly been the case. Finally, the SEC stated that "no-action" letters would no longer be available from the staff to confirm in advance of resale that any given individual had met the rigors of the intent test. ${ }^{40}$

Rule 144 states that it is available to affiliate's ${ }^{41}$ brokers and to persons who sell "restricted securities." 42 If a securities holder sells his securities in accordance with all of the conditions of the Rule, he is deemed not to have been engaged in a distribution of those securities and therefore not to have been an underwriter thereof. ${ }^{43}$ These conditions include a limitation on the volume of securities sold ${ }^{44}$ and the following requirements: that adequate public information regarding the issuer be available, ${ }^{45}$ that the sale be made through a normal brokerage transaction, ${ }^{46}$ and that there be public notice of

the word's 'with a view to' in the phrase 'purchased from an issuer with a view to ... distribution." SEC Securities Act Release No. 5223, at 4-5 (Jan. 11, 1972). With the adoption of Rule 144, the focus shifted to the word "distribution." See SEC Rulc 144(b), 17 C.F.R. $\$ 230.144($ b) (1974).

37. Data Packaging Corp., [1971-72 Transfer Binder] CCH Fed. SEc. L. REP. ๆ 78,549.

38. For a discussion of the various factors involved in the subjective intent test, see SEC Securities Act Release No. 5223 (Jan. 11, 1972); SEC Securities Act Release No. 4552 (Nov. 6, 1962); SEC Securities Act Release No. 285 (Jan. 24, 1935).

39. SEC Securities Act Release No. 5223, at 5 (Jan. 11, 1972).

40. Id. at $2-3$.

41. The term "affiliate" is not defined by the 1933 Act. SEC Rule 144(a)(1), 17 C.F.R. $\$ 230.144$ (a)(1) (1974), defines an affiliate of an issuer as "a person that directly, or indirectly through one or more intermediaries, controls, or is controlled by, or is under common control with, such issuer." It thus includes control persons within its scope. See SEC Rule 405(f), 17 C.F.R. $\$ 230.405(\mathrm{f})$ (1974), which defines control.

42. SEC Rule 144(b), 17 C.F.R. $\$ 230.144(b)$ (1974). Section (a)(3) of the Rule defines "restricted securities" as "securities acquired directly or indirectly from the issuer thereof, or from an affiliate of such issuer, in a transaction or chain of transactions not involving any public offering."

43. SEC Rule 144(b), 17 C.F.R. \$ 230.144(b) (1974).

44. SEC Rule 144(e), 17 C.F.R. $\$ 230.144$ (e) (1974).

45. SEC Rule 144(c), 17 C.F.R \$230.144(c) (1974).

46. SEC Rule 144(f), (g), 17 C.F.R. § 230.144(f), (g) (1974). 
the sale. ${ }^{47}$ When the securities holder is selling restricted securities, he must in addition have held the securities for at least two years. ${ }^{48}$

The provision for affiliate's brokers in effect enables the affiliate to rebut his presumed underwriter status as to his own nonrestricted securities, as long as the affiliate is not deemed an underwriter for some reason independent of his status as an affiliate. ${ }^{49}$ The "restricted securities" provision applies to those who wish to sell securities that fit the Rule's definition of that term: securities acquired from the issuer or affiliate "in a transaction ... not involving a public offering." 50 The SEC staff does not permit one deemed an underwriter because he is a substantial S-8 optionholder to rebut his status using this part of Rule 144, because in the staff's view S-8 securities are not restricted securities ${ }^{51}$ except in unusual situations. ${ }^{52}$ The rationale for registration of the option stock in the first place, the staff reasons, is that the offering does in one sense constitute a public offering to the optionees; the securities thus fall outside the definition in Rule 144. It is the staff's further opinion that the Rule is unavailable regardless of the substantial optionholder's status as an affiliate.53

Faced with the unattractiveness of the subjective intent test and the general unavailability of Rule 144, the substantial optionholder will find it difficult if not impossible to rebut his underwriter status, so that he is likely to be subject to the registration requirements.

The "control clause" of the statutory definition of an underwriter ${ }^{54}$ gives a control person underwriter status regardless of the proportion of an offering which he acquires. Prior to the adoption of Rule 144, a control person could rebut his underwriter status by selling his securities through a broker under former Rule $154 .{ }^{55}$ The optionee

47. SEC Rule 144(h), 17 C.F.R. $\$ 230.144$ (h) (1974).

48. SEC Rule 144(d), 17 C.F.R. \$ 230.144(d) (1974).

49. See SEC Securities Act Release No. 4818, at 2 (Jan. 21, 1966).

50. SEC Rule 144 (a)(3), 17 C.F.R. $\$ 230.144$ (a)(3) (1974).

51. Tracor, Inc., [1972-73 Transfer Binder] CCH FED. SEc. L. REP. If 79,276.

52. See Spectra-Physics, Inc., [1972-73 Transfer Binder] CCH Fed. SEC. L. Rer. If 79,190 (proposed S-8 offering to the company's top four executives deemed not to be a "public offering").

53. Tracor, Inc., [1972-73 Transfer Binder] CCH FED. SEC. L. REP. 79.276. The staff's prohibition against the substantial optionholder's using Rule 144 may also have been based on an inappropriate analogy to the staff's prohibition against a person's using Rule 144 who was engaged in a distribution for a commission, when such person acquires a substantial proportion of the offering. Klienberg, Bensley, Kaplan, and Wolff, [1971-72 Transfer Binder] CCH FED. SEC. L. REP. I 78,751. The rationale there appears to have been that such a person, by definition, acquired the securities for purposes of a distribution and not for investment. As such, Rule 144 could not be used to establish that such a person is not engaged in a distribution.

54. See the last sentence of the statutory definition of an underwriter, Securities Act of $1933 \S 2(11)$, 15 U.S.C. $\$ 77 \mathrm{~b}(11)$ (1970) (quoted in note 32 supra).

55. SEC Rule 154, 17 C.F.R. $\$ 230.154$ (1970), rescinded, SEC Securities Act Release No. 5223 (Jan. 11, 1972). Although former Rule 154 exempted only the broker's 
who is both a control person and a substantial optionholder can no longer avail himself of this method of exemption, but a control person who is not a substantial optionholder fares better. Under the staff's interpretation, he may employ Rule 144 to rebut his underwriter status, but only if an effective registration statement is not available ${ }^{50}$ for his use at the time of resale. ${ }^{57}$ When a control person cannot avail himself of Rule 144, he, like the substantial optionholder, will find it difficult if not impossible to rebut his underwriter status, so that he too is likely to be subject to the registration requirements.

\section{B. Which Registration Statement is Required}

At one time the SEC required registration of S-8 securities on Form S-1 prior to resale by an underwriter, even if the sale were to occur on an exchange in an ordinary brokerage transaction. ${ }^{58}$ As currently amended, Undertaking $\mathrm{C}$ of Form S-8 requires the issuer to expand the S-8 prospectus to include Form S-1 information prior to a resale of S-8 securities ${ }^{59}$ by an underwriter otherwise than on a national securities exchange. ${ }^{60}$ This suggests that an expanded S-8 prospectus is not required for a resale made on an exchange. The staff has sanctioned this interpretation, specifically stating that an unexpanded Form S-8 that is current would be sufficient in such a case. ${ }^{01}$

part of the transaction, the control person would ordinarily be able to overcome his underwriter status if his broker had met all the conditions of Rule 154, so long as the control person was not deemed an underwriter for some reason independent of his status as a control person. SEC Securities Act Release No. 4818, at 2 (Jan. 21, 1966). 56. See note 27 supra \& text accompanying notes 58-61 infra.

57. Tracor, Inc., [1972-73 Transfer Binder] CCH FED. SEc. L. REP. T 79,276; American Standard, Inc., [1972-73 Transfer Binder] CCH FED. SEC. L. REP. T 79,071.

58. It has been suggested that this requirement was imposed out of a "concern that [Form S.8] may be misused for redistributions, for example, by banks foreclosing on loans secured by optioned shares pledged to finance the purchase price." Apparently it was withdrawn out of a fear of discouraging the use of Form S-8 altogether when the number of optionees is small enough to make the private offering exemption available. 4 L. Loss, Securities Regulation 2363 (Supp. 1966).

59. The wording of Undertaking $G$ makes its requirements applicable only to restricted stock options. However, the staff has apparently interpreted the requirements of Undertaking $\mathrm{C}$ as applying as to all securities registered on Form S-8. See Tracor, Inc., [1972-73 Transfer Binder] CCH FED. SEC. L. REP. I 79,276 (no distinction made as to the type of stock / option plan involved); American Standard, Inc., [1972-73 Transfer Binder] CCH FED. SEC. L. REP. \$ 79,071 (same); Data Packaging Corp., [1971-72 Transfer Binder] CCH FED. SEC. L. REP. \$8,549 (Undertaking C applies to a qualified stock option plan). The staff's view appears to be that the wording of Undertaking $\mathbf{C}$ inadvertently was not amended when Form S-8 was made available for other than restricted stock options.

60. SEC Form S-8, Undertaking C, 1 CCH Fed. SEC. L. REP. 77200 (1974). Undertaking $C$ was first introduced in 1962. At that time, the amount of information publicly available concerning listed companies was significantly greater than that available for most unlisted companies. Because of the increased information available for NASDAQ-listed companies, Undertaking $C$ has become an anachronism. See Dykstra \&: Reynolds, $A$ Review of Form $S-\delta, 5$ Rev. OF SEC. REg. 871 (1972).

61. Northrup Stock Option Plan, [1972-73 Transfer Binder] CCH FED. SEC. L. REP. I 79,230; American Standard, Inc., [1972-73 Transfer Binder] CCH FED. SEC. L. REP. 


\section{Toward a New Regulatory Framework}

A resale of S-8 securities should indeed be subject to some restrictions. Form S-8 does not provide the intense scrutiny of the original offering which would have been provided by Form S-1, were it required, and there is a danger that an S-8 offering may be used to dump securities on the open market. The SEC has appropriately focused its regulatory efforts on substantial optionholders and control perşons, for they are the ones most likely to endanger the investing public by unregulated resale of S-8 securities. As noted above, the SEC staff carries out this policy by establishing a presumption that substantial optionholders and control persons are underwriters, then denying to most persons within those categories the use of Rule 144 to rebut the presumption. The staff's position is apparently grounded on the reasoning in SEC Securities Act Release No. 5306: "To permit the use of Rule 144 under such circumstances would be inconsistent with the broad remedial purposes of the [1933] Act and with public policy which strongly supports registration." ${ }_{62}$ Registration is desirable under this view because of the disclosure which it affords, and because it subjects an underwriter to civil liability ${ }^{63}$ for false or misleading information contained in the registration statement.

But the SEC may well be working from faulty premises. The dangers attendant upon resale of S-8 securities are substantially the very dangers attendant upon the resale of restricted securities, ${ }^{64}$ and it is wrong to treat the two so differently. Indeed, although the SEC staff has adopted the opposite view, there is an important sense in which the definition of restricted securities ${ }^{65}$ includes S-8 securities. The SEC's rationale ${ }^{66}$ for permitting the use of the shorter Form S-8 is based on a theoretical distinction between the optionees and the investing public. In this perspective an S-8 offering is not truly a public offering. The protective device designed specifically to regulate the resale of restricted securities-Rule 144-should therefore be relied upon in principle for the resale of S-8 securities.

There is a more fundamental objection to the current regulatory approach as reflected in Release No. 5306. The reliance placed on

I 79,071; Capitol Industries, Inc., [1971-72 Transfer Binder] CCH FED. SEC. L. REP. 178,438; Sorg Paper Co., [1971-72 Transfer Binder] CCH FED. SEC. L. REP. If 78,541. The negative pregnant of Undertaking $C$ is apparently the only source of authority for this use of Form S-8.

62. SEC Securities Act Release No. 5306, at 2 (Sept. 26, 1972).

63. Securities Act of $1933 \S 11$ (a)(5), 15 U.S.C. $\$ 77 \mathrm{k}(\mathrm{a})(5)$ (1970).

64. See Note, supra note 14 , at $1575-80$.

65. See note 42 supra.

66. See note 15 supra. 
the broad virtues of registration is uncritical, and it has led to less protection upon resale of S-8 securities than might be obtained. Such reliance ignores the fact that "registration" does not inevitably mean the fullest disclosure. The SEC itself permits many of the resales here involved to take place under Form S-8. In such cases the only possible improvement in investor protection over the use of Rule 144 lies in the optionee's becoming civilly liable for false and misleading information. It will be seen that this protection is largely unfair and somewhat illusory. Use of Form S-8, like the use of Rule 144, ${ }^{67}$ is predicated upon the issuer's being a reporting company. The additional information supplied to the investing public by the S-8 prospectus is negligible. ${ }^{88}$ Rule 144 , on the other hand, even as applied to nonrestricted securities, ${ }^{69}$ supplies additional safeguards. It limits the volume of securities sold at any one time, ${ }^{70}$ it carefully prescribes the type of transaction by means of which the holder may resell, ${ }^{71}$ and it requires public notice. ${ }^{72}$

Moreover, uncritical reliance upon registration causes two more undesirable results. First, the optionee incurs civil liability when resales are made under a registration statement. This may be unfair in some instances. As the SEC itself has said, there is some question whether the liability which adheres to those with underwriter status should be imposed upon those who are not necessarily in a position to investigate with due diligence the accuracy of the information supplied in a registration statement. ${ }^{73}$ If a person who is not in a position to

67. SEC Rule 144(c)(1), 17 C.F.R. $\$ 230.144(c)(1)$ (1974). While Rule 144(c)(2) provides an exception to this requirement which may be applicable (see note 26 supra), it also provides alternative protection in such cases. SEC Rule 144(c)(2), 17 C.F.R. $\S 230.144(c)(2)(1974)$.

68. See note 24 supra.

69. Rule 144 applies in its various provisions to both restricted and nonrestricted securities. SEC Rule 144(b), (d), 17 C.F.R. $\$ 230.144(b)$, (d) (1974). Three out of four of the Rule's protective provisions-the limitations on volume and transaction type, and the public notice requirement-apply to both. The only additional condition im: posed on restricted securities is that they must be held for a two-year period. SEG Rule 144(d), 17 C.F.R. $\$ 230.144$ (d) (1974).

If the analogy between $S-8$ securities and restricted securities were exact, $S \cdot 8$ securities should be subject to such a holding period. However, $S \cdot 8$ securities occupy a twilight zone, partaking of some of the characteristics of a public offering. Compare the position advanced on p. 95 supra, with the SEC staff position presented in Tracor, Inc., [1972-73 Transfer Binder] CCH FED. SEC. L. REP. I 79,276. Moreover the business needs which give rise to stock options make it less likely in practice that such options are open to the abuses possible through private placements. Therefore, this Note takes the position that the two-year holding requirement is an unnecessary burden for S-8 optionees. All of the other safeguards in Rule 144 should apply. For brevity (and not to indicate policy underpinnings) the Note refers to this type of regulation as that applied by Rule 144 to nonrestricted securities.

70. SEC Rule 144(e), 17 C.F.R. \$ 230.144(e) (1974).

71. SEC Rule 144(f), (g) 17 C.F.R. \$ 230.144(f), (g) (1974).

72. SEC Rule 144(h), 17 C.F.R. $\$ 230.144(\mathrm{~h})(1974)$.

73. SEC Securities Act Release No. 5316, at 8 (Oct. 6, 1972). The SEC raised this point in the context of resales of securities acquired under SEC Form S-14, 17 C.F.R. 
perform such an investigation may take advantage of Rule 144, he will not incur civil liability for something over which he has no control.

Second, on the occasions when the S-8 prospectus must be expanded to include Form S-1 information prior to resale, the liquidity of the S-8 securities may be significantly impaired. The expense to the issuer of supplying the additional S-1 information can be sufficiently great to inhibit his cooperation unless an S-1 registration statement is otherwise available. ${ }^{74}$ The alternative protection afforded by Rule 144 is provided to overcome this problem in regard to restricted securities, and should be available here, as the danger inherent in the resale of S-8 securities is no greater than that inherent in the resale of restricted securities or non-S-8 securities held by control persons.

These considerations suggest that once a holder of S-8 securities is identified as an underwriter, he should be required to resell his securities in accordance with the provisions of Rule 144 as they apply to nonrestricted securities, rather than under a registration statement, regardless of his status as a substantial optionholder, his status as a control person, or the issuer's status as a listed or unlisted company.

$\$ 239.23$ (1974) (used to register offerings in connection with certain business combinations). Much of the discussion in this Note would appear to be relevant to the resale of securities acquired under Form S-14, as well as to the resale of securities acquired under SEC Form S-16, 17 C.F.R. \$ 239.27 (1974) (available to issuers that have an established record of earnings and continuity of management, for the registration of securities in connection with warrants, convertible securities, and for sales of certain other outstanding securities).

74. As the expense to the issuer increases, the optionee's leverage, individually or combined with that of others similarly situated, must also increase to induce the issuer to make the expanded information available. 